\title{
Pengembangan Sistem Informasi Penerimaan Jasa Servis di Bengkel Motor dengan Model Prototype
}

\author{
Tri Retnasari ${ }^{1}$, Eva Rahmawati ${ }^{2}$, Cahyo Pambudi ${ }^{3}$ \\ ${ }^{1,2}$ Program studi Teknik Informatika, STMIK Nusa Mandiri Jakarta \\ ${ }^{3}$ Program studi Komputerisasi Akuntansi, AMIK Bina Sarana Informatika Jakarta \\ 1retna3sari@gmail.com \\ 2 pambudic@rocketmail.com \\ 3 eva_rijal@gmail.com
}

\begin{abstract}
Abstrak- Pertumbuhan sepeda motor dari tahun ketahun naik secara signifikan, hal ini berbanding lurus dengan munculnya bengkel-bengkel sepeda motor untuk memenuhi kebutuhan konsumen memperbaiki atau merawat kendaraan yang dimilikinya agar berjalan dengan baik. Kenaikan jumlah sepeda motor di Indonesia ini menimbulkan peluang besar bagi pengusaha untuk membuka usaha dibidang service sepeda motor, mulai dari bengkel skala kecil hingga besar pun bermunculan. Namun dalam memudahkan berjalannya usaha dibidang service sepeda motor ini, hanya bengkel-bengkel skala besar atau bengkel dengan status Agen Tunggal Pemegang Merek sajalah yang menerapkan sistem terkomputerisasi. Masih banyak bidang usaha service sepeda motor ini yang belum menggunakan sistem terkomputerisasi untuk mendukung berjalannya usaha. Berdasarkan hal tersebut, penulis membuat suatu sistem informasi penerimaan jasa service sepeda motor yang dapat membantu bagi organisasi dan perusahan kecil. Sistem ini memungkinkan pengguna secara dengan cepat memahami cara penggunaan sistem terkomputerisasi untuk mendukung proses penerimaan jasa service dikarenakan tampilan yang digunakan bersifat user friendly. Model pengembangan sistem yang digunakan dalam perancangan sistem ini menggunakan model Unified Modeling Language (UML), serta sistem ini mendukung pengolahan data master, transaksi hingga menampilkan laporan yang dibutuhkan, serta sistem ini mendukung adanya hak akses dan perekaman siapa saja yang menggunakan sistem. Aplikasi ini dirancang dengan menggunakan metode prototype yang bertujuan agar proses perancangan dah hasil akhir aplikasi yang dibuat dapat digunakan sesuai dengan kebutuhan Bengkel.
\end{abstract}

Kata Kunci-Model Prototype, UML, Sistem Informasi.

\section{PENDAHULUAN}

Semakin berkembangnya zaman, pertumbuhan kendaraan pribadi khususnya sepeda motor sangat pesat. Hal ini berbanding lurus dengan bertumbuhnya penyedia jasa servis kendaraan. Namun masuknya sistem teknologi informasi ke Indonesia belum dimanfaatkan sepenuhnya oleh para penyedia jasa servis sepeda

yang kurang aman. Dalam perkembangannya, komputer tidak hanya digunakan untuk memproses, menyimpan dan mengolah data menjadi informasi, namun komputer juga dituntut untuk bisa memecahkan suatu masalah serta membantu menyelesaikan pekerjaan lainnya yang diinginkan oleh pengguna secara cepat, tepat dan akurat. Tak hanya itu, Setiap perusahaan mencoba untuk menerapkan sistem informasi agar dapat meningkatkan efisiensi dan efektifitas dalam proses bisnis, sehingga berinvestasi dalam teknologi informasi sangatlah penting untuk memberikan kekuatan bagi perusahaan agar dapat bersaing dan dapat mendungkung perusahaan dalam mengambil keputusan [2]. motor khusus skala menengah untuk mendukung proses bisnis yang terjadi. Hal ini disebabkan karena masih kurangnya pengetahuan pegawai mengenal sistem terkomputerisasi. Dilihat dari sisi positif, dengan menggunakan sistem terkomputerisasi, perusahaan dapat melakukan pengelolaan data secara lebih cepat, tepat dan akurat. Sejak komputer ditemukan dan program aplikasi dibuat oleh banyak vendor, muncullah berbagai macam bentuk program aplikasi. Pada generasi awal dikenal program aplikasi berbasis desktop (desktop based), lalu diawal tahun 90-an) [1]. Penerapan teknologi informasi dalam bidang bisnis merupakan salah satu contoh untuk memenuhi akan kebutuhan informasi yang demikian besar terlebih lagi teknologi ini juga mempunyai nilai akurasi data yang tinggi dalam menunjang keputusan bisnis sehingga pekerjaan akan jauh lebih efektif dan efisien. Teknologi informasi tidak hanya terbatas pada teknologi komputer (perangkat keras dan perangkat lunak) yang akan digunakan untuk memproses dan menyimpan informasi, melainkan juga mencakup teknologi komunikasi untuk mengirim atau menyebarkan informasi pendukung keputusan dan sistem informasi.

Sebagai bukti dalam bidang otomotif roda dua, banyaknya bengkel-bengkel motor yang menjamur di Indonesia khususnya di Jakarta dapat dipastikan hanya bengkel skala besar atau bengkel dengan status Agen Tunggal Pemegang Merek (ATPM) yang menggunakan sistem terkomputerisasi dalam mengelola penerimaan jasa servis dari usaha yang dijalankan. Sedangkan bengkel skala menengah yang masih melakukan pengolahan data penerimaan jasa servis secara manual mempunyai banyak kelemahan, selain membutuhkan waktu dan tenaga yang lebih, keakuratannya pun juga kurang dapat diterima karena kemungkinan kesalahannya sangat besar dan hal yang paling penting adalah penyimpanan data

Pada penelitian sebelumnya yaitu membahas kegiatan operasional bengkel baik dalam pelayanan transaksi dan pengolahan laporan keuangan menggunakan Metode Rapid Application Development (RAD). Adapun tahapan metode RAD meliputi investigasi awal, analisis masalah, analisis kebutuhan sistem, analisis cost benefit, pembuatan database dan perancangan prototype [3].

Dengan adanya sistem penerimaan jasa diharapkan membantu organisasi dan perusahan kecil bengkel secara dengan cepat memahami cara penggunaan sistem terkomputerisasi untuk mendukung proses penerimaan jasa service dikarenakan tampilan yang digunakan bersifat user 
friendly. Sistem ini juga mendukung pengolahan data master, transaksi hingga menampilkan laporan yang dibutuhkan, serta sistem ini mendukung adanya hak akses dan perekaman siapa saja yang menggunakan sistem.

\section{II.TINJAUAN PUSTAKA}

A. Program

Dalam pengertiannya, menurut [7] program dapat 1 . didefinisikan sebagai "Algoritma yang ditulis dalam bahasa 2 komputer". Sedangkan menurut [8] menjelaskan bahwa "Program merupakan sederetan instruksi atau statement dalam 3 . bahasa yang dimengerti oleh komputer yang bersangkutan".

Adapun tujuan pembuatan program diantaranya :

1. Membuat solusi dan pemecahan masalah dari kasus yang ada.

2. Meningkatkan kualitas dan performa kerja.

3. Membantu proses pengambilan keputusan.

Pembuatan program tidak terlepas dari tahapan-tahapan yang harus dilakukan secara terstruktur untuk membantu programmer dalam menyelesaikan programnya dengan baik. Untuk membuat suatu program yang kompleks, tahapantahapan yang dilakukan adalah sebagai berikut:

1. Mendefinisikan masalah

2. Analisa kebutuhan

3. Membuat rumusan pemecahan masalah

4. Pengkodean program

5. Bahasa pemrograman

6. Testing dan debugging

7. Dokumentasi

8. Pemeliharaan

Sedangkan untuk membuat suatu program sederhana, programmer hanya perlu melakukan beberapa tahapan saja, yaitu:

1. Definisi masalah

2. Desain algoritma

3. Bahan pemrograman

4. Testing dan debugging

\section{B. Basis Data (Database)}

Basis data atau database menurut [9] adalah "Sebuah koleksi atau kumpulan data yang saling berhubungan (relation), disusun menurut aturan tertentu secara logis, sehingga menghasilkan informasi".

Sedangkan menurut [10] menjelaskan bahwa database adalah "Sebagai kumpulan terorganisasi dari data-data yang berhubungan sedemikian rupa sehingga mudah disimpan, dimanipulasi, serta dipanggil penggunanya".

\section{MYSQL}

Menurut [11] menjelaskan bahwa "SQL (Structured Query Language) adalah sebuah bahasa yang dipergunakan untuk mengakses data dalam basis data relasional”. SQL juga dapat diartikan sebagai antar muka standar untuk sistem manajemen basis data relasional, termasuk sistem yang beroperasi pada komputer pribadi.

D. Pengertian Penerimaan Kas

Menurut [11] menerangkan bahwa penerimaan adalah "Peningkatan dalam aktiva suatu organisasi atau penurunan dalam kewajiban-kewajiban selama suatu periode akuntansi, terutama yang berasal dari aktiva operasi”.

E. Jurnal Penerimaan Kas

Menurut [12] menerangkan bahwa "Jurnal Penerimaan Kas adalah jurnal yang disediakan khusus untuk transaksi penerimaan kas". Penerimaan kas pada suatu perusahaan dikelompokkan menjadi tiga golongan yaitu:

Penerimaan kas dari penjualan tunai

Penerimaan kas dari para debitur yang membayar kewajibannya

Penerimaan kas dari sumber-sumber lain

Contoh dari jurnal penerimaan kas sebagai berikut :

Kas

Pendapatan $\quad \mathrm{xxx}$

F. Unified Modeling Language (UML)

Menurut [13] menerangkan bahwa "UML muncul karena adanya kebutuhan pemodelan visual untuk menspesifikasikan, menggambarkan, membangun, dan dokumentasi dari sistem perangkat lunak".

Menurut [13], pada UML 2.3 terdiri dari 13 macam diagram yang dikelompokan dalam 3 kategori. Pembagian kategori dan macam-macam diagram tersebut dapat dilihat pada gambar dibawah ini:

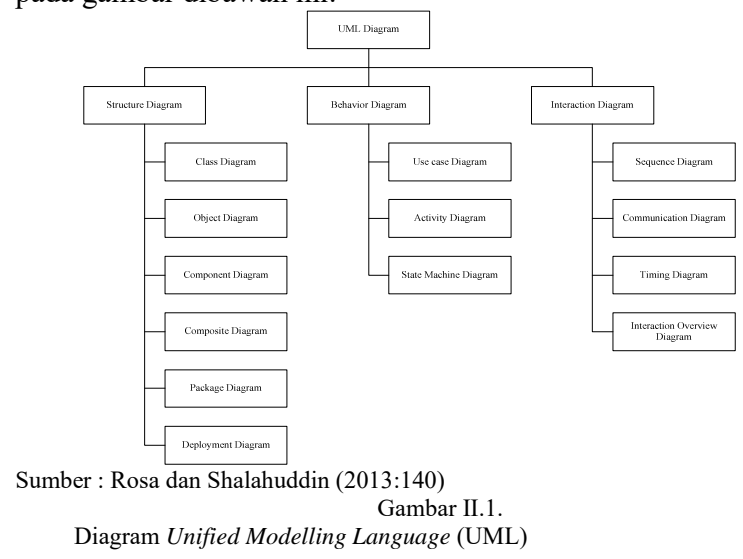

G. Use Case Diagram

Menurut [13] menjelaskan bahwa "Use case atau diagram use case merupakan pemodelan untuk kelakuan (behavior) sistem informasi yang akan dibuat".

\section{H. Activity Diagram}

Menurut [13] mengatakan bahwa "Diagram aktivitas atau activity diagram menggunakan workflow (aliran kerja) atau aktivitas dari sebuah sistem atau proses bisnis atau menu yang ada pada perangkat lunak".

I. Entity Relationship Diagram (ERD)

Menurut [13] mengatakan bahwa "Entity Relationship Diagram (ERD) dikembangkan berdasarkan teori himpunan dalam bidang matematika. ERD digunakan untuk pemodelan 
JIEET: Volume 02 Nomor 01, 2018

basis data relasional". Berikut adalah komponen dari Entity 4. Relationship Diagram (ERD):

1. $\quad$ Entitas (Entity)

Entitas adalah sesuatu yang nyata atau abstrak dimana kita akan menyimpan data.

2. Relasi (Relationship)

Relasi adalah hubungan alamiah yang terjadi antara satu atau lebih entitas, misalnya : proses penerimaan jasa servis.

3. Atribut (Atribute)

Atribut adalah ciri umum semua atau sebagian besar instansi pada entitas tertentu. Sebutan lain atribut adalah properti, elemen data dan field. Misalnya nama, alamat, nomor pegawai, gaji adalah atribut dari entitas pegawai. Sebuah atribut atau kombinasi atribut yang mengidentifikasi satu dan hanya satu instansi suatu entitas disebut kunci utama atau pengenalan.

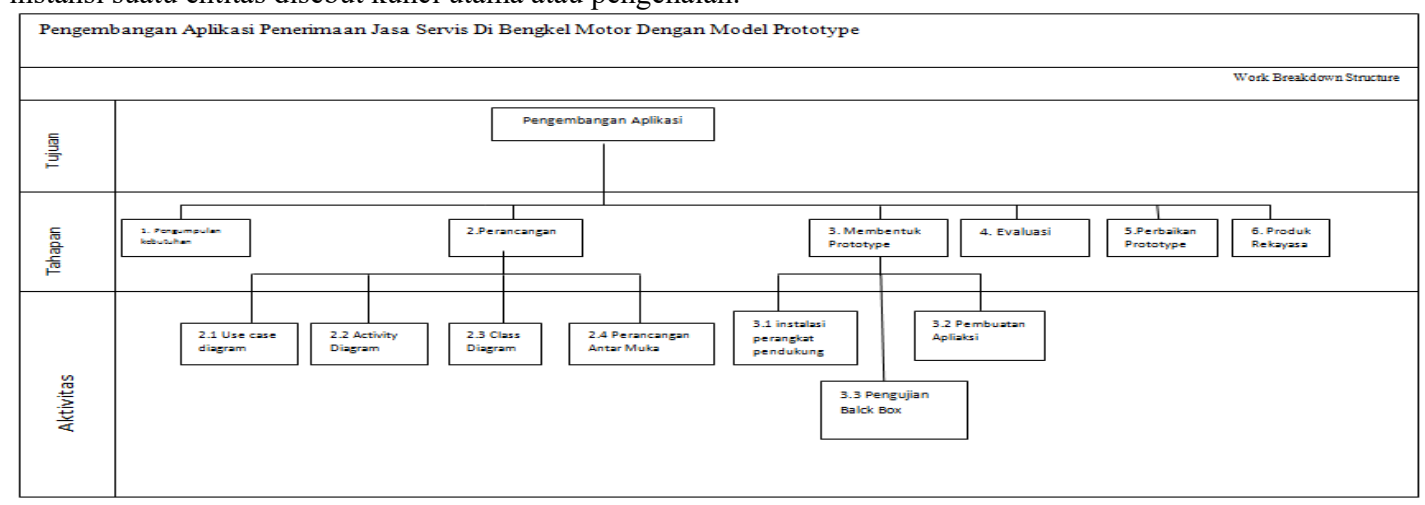

\section{METODE PENELITIAN}

Dalam penelitian ini, dilakukan beberapa tahapan untuk mencapai tujuan yang direncanakan.

Gambar 2. Work Breakdown Structure Penelitian

Tahap pengumpulan kebutuhan dan perbaikan merupakan proses melakukan pengumpulan bahan atau data yang sesuai dengan penelitian. Dalam Proses pengumpulan data dilakukan studi literatur terhadap aplikasi yang serupa terhadap penelitian sebelumnya.

Tahapan perancangan dan pembentukan prototype penulis gunakan, yaitu:

a. Analisa kebutuhan software

Dalam tahap ini, dilakukan analisa permasalahan terlebih dahulu yang kemudian dikembangkan menjadi suatu logika urutan proses untuk menyelesaikan suatu masalah. Dengan menganalisa kebutuhan software, seorang programmer dapat menentukkan spesifikasi dari fungsi, kemampuan dan fasilitas dari program yang akan dibuat sehingga bermanfaat untuk evaluasi setelah pembuatan program. Model pengembangan sistem yang digunakan dalam perancangan sistem ini menggunakan model Unified Modeling Language (UML).

b. Desain

Dalam pembuatan penulisan ini, penulis menggunakan satu database MySQL yang berisi 8 tabel yang terdiri dari tabel cutomer, pegawai, technician, jenis service, sparepart, transaksi, detail transaksi dan riwayat login. Sedangkan user interface dibuat dengan memperhatikan kemudahan dalam pengoperasiannya karena biasanya user interface dibuat dalam bentuk dialog yang saling berhubungan antara menu, tombol dan layar. User interface yang penulis buat yaitu Form Menu
Utama, Form Customer, Form Jenis Service, Form Technician, Form Pegawai, Form Sparepart, Form Transaksi, Form Pemilihan Data Customer, Form Pemilihan Data Jenis Service, Form Pemilihan Data Technician, Form Pemilihan Data Sparepart, Form Cetak Laporan Harian, Form Cetak Laporan Bulanan, Form Cetak Laporan Tahunan, Form Cetak Riwayat Pengguna, Form Login, Form Ganti Password, Form About Programmer, Form Backup dan Form Restore.

c. Code Generation

Dalam pembuatan penulisan ini, penulis menggunakan bahasa pemrograman java dan program yang dibuat termasuk jenis pemrograman terstruktur dengan bantuan Netbeans ide 8.1, Xampp control panel v3.2.2, Java Development Kit versi 8.0.730.2 dan iReport untuk membuat laporan-laporan dan faktur yang dibutuhkan sistem ini.

d. Testing

Disini penulis menggunakan Black Box Testing yang berarti menguji perangkat lunak dari segi spesifikasi fungsional tanpa menguji desain dan kode program. Pengujian ini dimaksudkan untuk mengetahui apakah fungsi-fungsi, masukkan dan keluaran dari perangkat lunak sesuai dengan spesifikasi yang dibutuhkan.

e. Support

Ini merupakan tahap terakhir dalam metode pengembangan software model waterfall. Untuk menjalankan software ini dibutuhkan basis data MySQL, Java Development Kit dan sistem operasi yang sudah dicoba adalah Microsoft Windows. 
Disamping itu diperlukan spesifikasi minimum hardware antara lain Processor Celeron CPU 1005M@1.90GHz, RAM dengan kapasitas 2GB dan Hard Disk dengan kapasitas 500 b GB.

Tahapan evaluasi pelanggan terhadap prototype merupakan tahapan pengujian aplikasi yang sebelumnya dihasilkan dalam tahapan bentuk prototype yang dilakukan oleh pengguna perangkat berbasis Dekstop. Tahapan ini dilakukan dengan melakukan pengujian dan pengisian lembar kuesioner evaluasi kepada pengguna perangkat berbasis Dekstop. Tahapan perbaikan prototype merupakan tahapan dimana dilakukan perbaikan kesalahan atau kelemahan-kelemahan yang terdapat pada aplikasi yang telah dibangun. Tahapan perbaikan prototype dilakukan berdasarkan hasil pengujian yang telah dilakukan sebelumnya oleh pengembang dan responden.

Tahapan produk rekayasa merupakan tahapan dimana produk yang sudah jadi dan siap digunakan oleh pengguna.

\section{Analisa Kebutuhan}

\section{HASIL DAN ANALISA}

Analisis kebutuhan diperlukan untuk mengetahui lebih jelas gambaran dan cara kerja sistem yang ada. Selain itu analisis kebutuhan bertujuan untuk mendefinisikan dan mengevaluasi permasalahan, kesempatan, hambatan yang terjadi dan kebutuhan-kebutuhan yang diharapkan sehingga dapat diusulkan suatu perbaikan.

a. Proses Input, Update dan Hapus Data Master

Data master yang terdapat di database program penerimaan jasa service adalah tabel customer, tabel pegawai, tabel sparepart, tabel jenis service dan tabel technician. Semua data diinput oleh pegawai yang mempunyai hak akses sebagai administrasi, sedangkan pegawai yang mempunyai hak akses sebagai kasir hanya bisa menginput data traksaksi penerimaan jasa service serta laporan penerimaan jasa service. Untuk pegawai yang mempunyai jabatan sebagai technician tidak dapat menggunakan aplikasi penerimaan jasa service baik itu merubah data master maupun menginput transaksi yang terjadi.

Proses Penginputan Transaksi Penerimaan Jasa Service dan Pencetakan Faktur

Customer memberikan penjelasan mengenai masalah sepeda motornya kebagian administrasi yang selanjutnya akan diteruskan ke bagian technician dan sekaligus menyerahkan Surat Tanda Nomor Kendaraan (STNK) beserta Kartu Member (Member Card) kepada bagian administrasi sebagai bukti keaslian kendaraan dan pemeriksaan apakah data customer tersebut sudah terdaftar atau belum sebagai member. Jika belum terdaftar, customer diberi 2 pilihan apakah ingin menjadi member atau tidak. Jika ingin menjadi member maka bagian administrasi akan membuat data customer baru dengan meminta Kartu Tanda Penduduk kepada customer sebagai data penginputan customer. Jika data customer sudah ada atau bisa dibilang sudah terdaftar sebagai member maka customer diminta menunggu selama proses service sepeda motor berjalan. Jika sepeda motor customer telah selesai diservice kemudian bagian kasir akan melakukan penginputan transaksi service yang terjadi berdasarkan informasi dari bagian technician dan customer diminta menuju kasir untuk proses pembayaran. Jika proses pembayaran telah selesai, customer diberikan faktur sebagai bukti transaksi service yang telah dilakukan.

c. Proses Pencetakan Laporan Penerimaan Jasa Service

Laporan diambil dari rekapitulasi pada tabel data transaksi dengan tabel detail transaksi. Bagian administrasi maupun bagian kasir dapat melakukan pencetakan laporan penerimaan jasa service yang selanjutnya diserhkan kepada pemilik bengkel.

\section{A. Use Case}

Use case atau diagram use case merupakan pemodelan untuk kelakuan (behavior) sistem informasi yang akan dibuat [4]. 


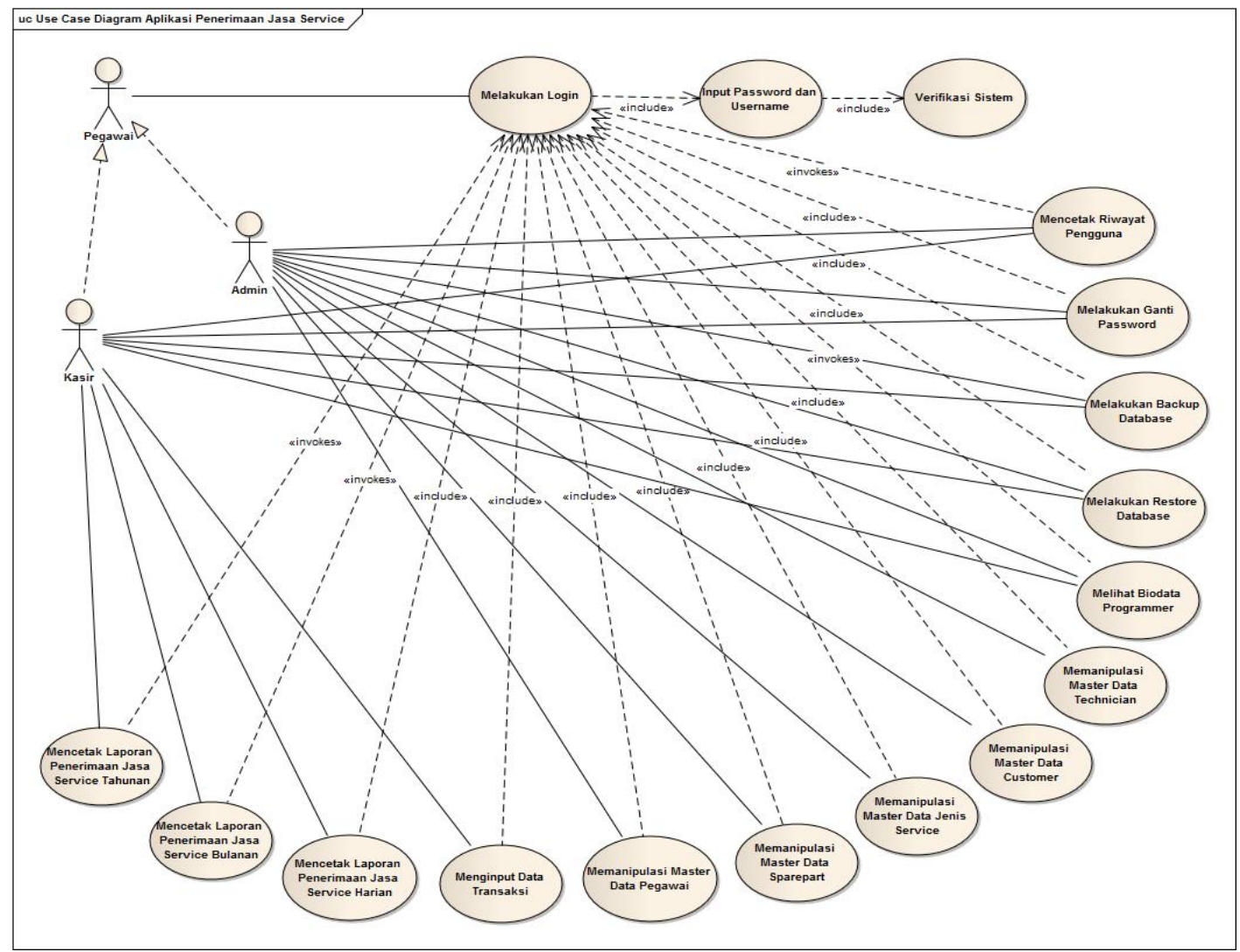

Gambar 3. Use Case Diagram Aplikasi Penerimaan Jasa Service

\section{B. Entity Relation Diagram (ERD)}

Entity Relationship Diagram (ERD) dikembangkan berdasarkan teori himpunan dalam bidang matematika. ERD digunakan untuk pemodelan basis data relasional [4]. 


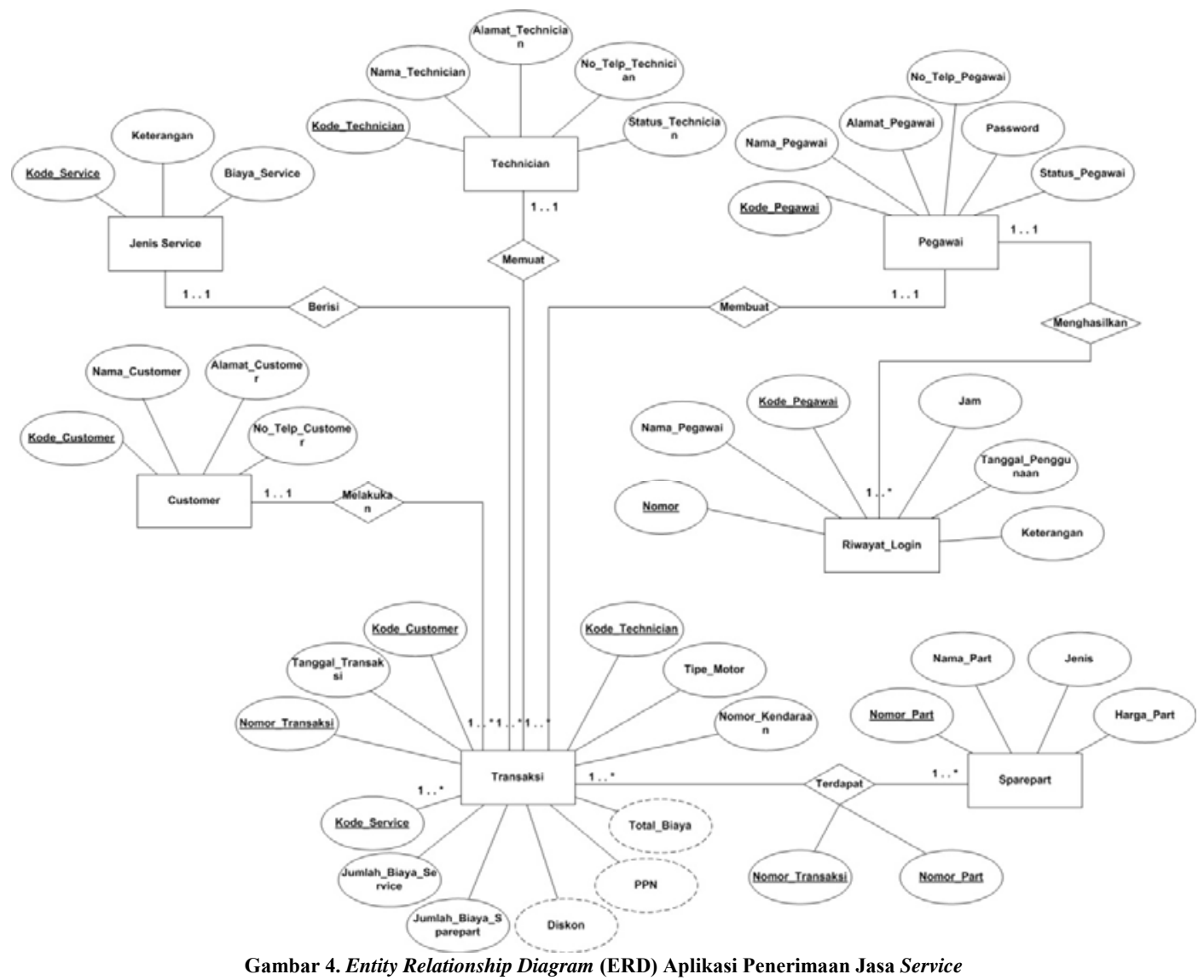

\section{Logical Record Structure (LRS)}

Logical Record Structure adalah Sebuah model sistem yang digambarkan dengan sebuah diagram-ER akan mengikuti pola atau aturan permodelan tertentu dalam kaitanya dengan konvensi ke LRS [5].

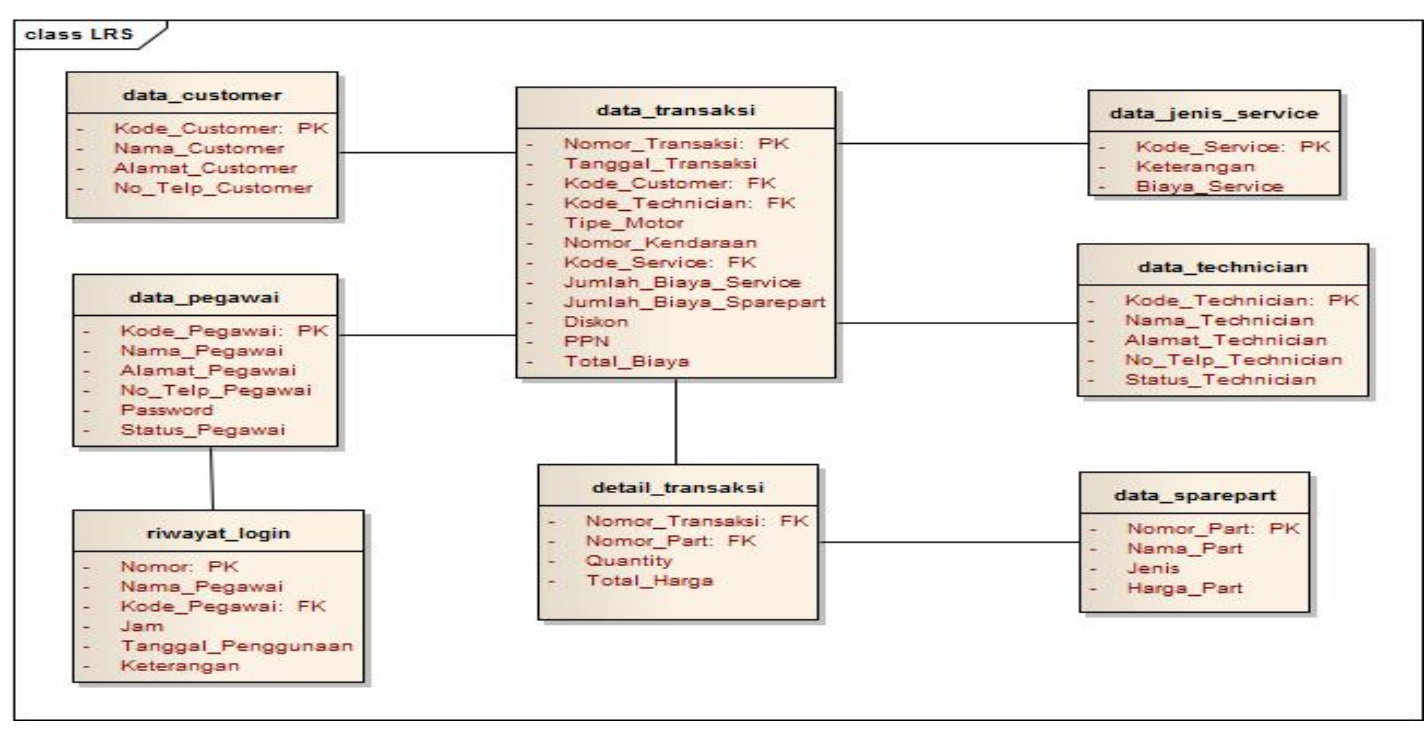

Gambar 5. Logical Record Structure (LRS) Aplikasi Penerimaan Jasa Service 


\subsection{User Interface}

User interface adalah interface yang dibuat untuk user [6]. Biasanya user interface ini dibuat dalam bentuk dialog yang saling berhubungan antara menu, tombol, dan layar.

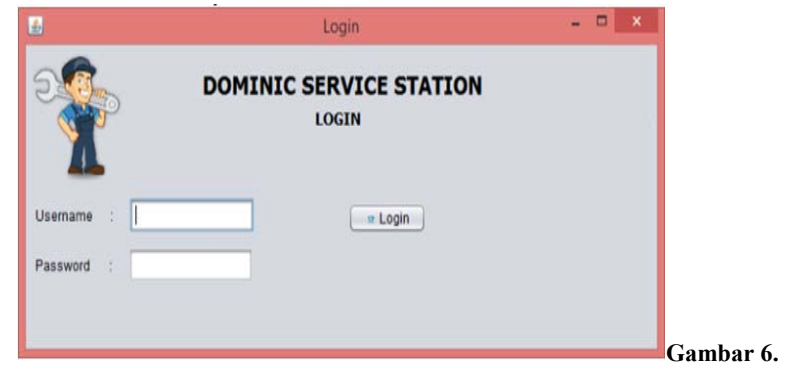

User Interface Login Aplikasi Penerimaan Jasa Service

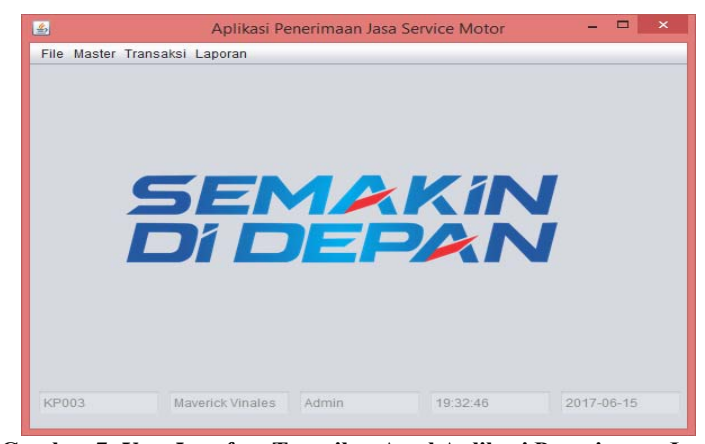

Gambar 7. User Interface Tampilan Awal Aplikasi Penerimaan Jasa Service

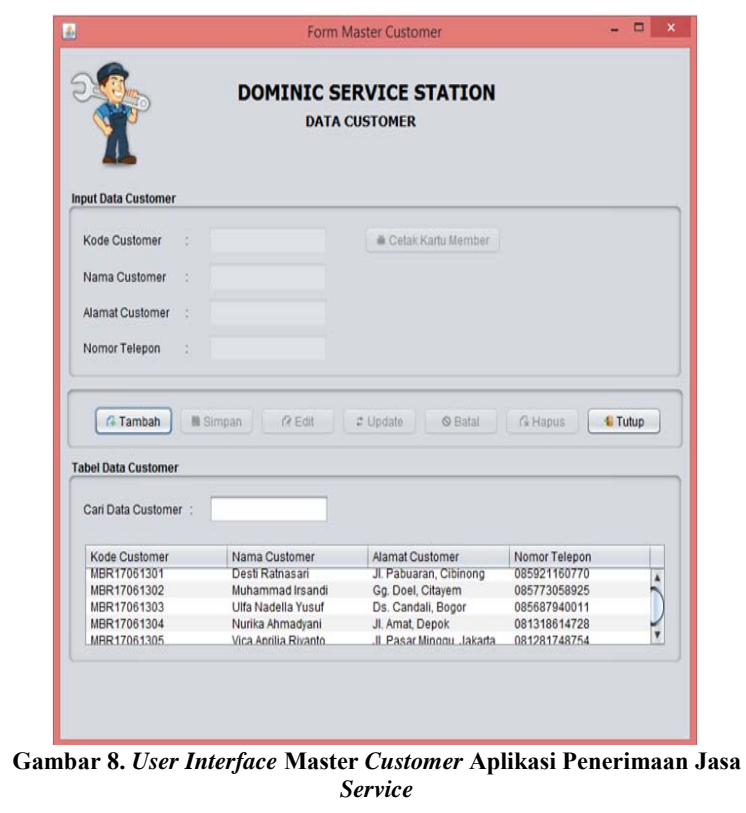

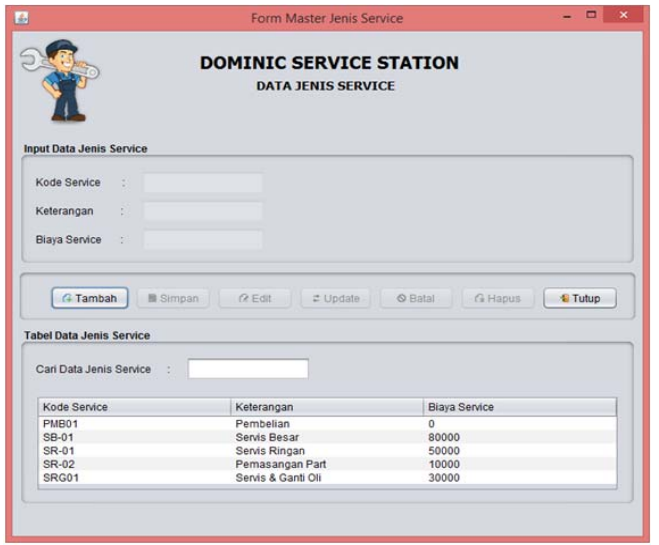

Gambar 9. User Interface Master Jenis Service Aplikasi Penerimaan Jasa Service

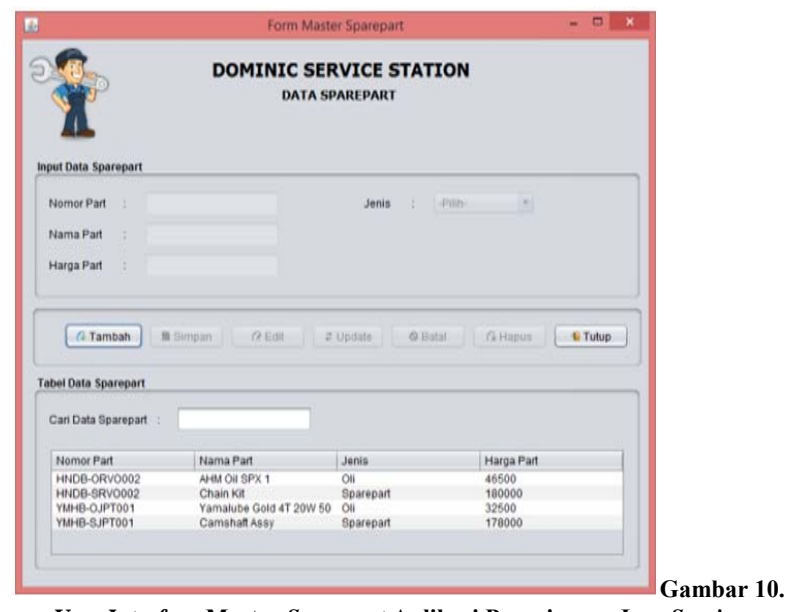

User Interface Master Sparepart Aplikasi Penerimaan Jasa Service

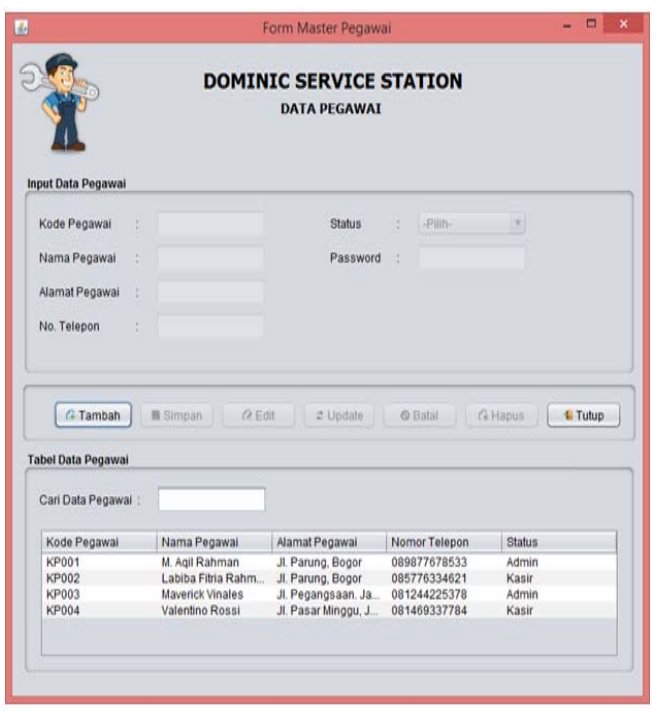

Gambar 11. User Interface Master Pegawai Aplikasi Penerimaan Jasa Service 


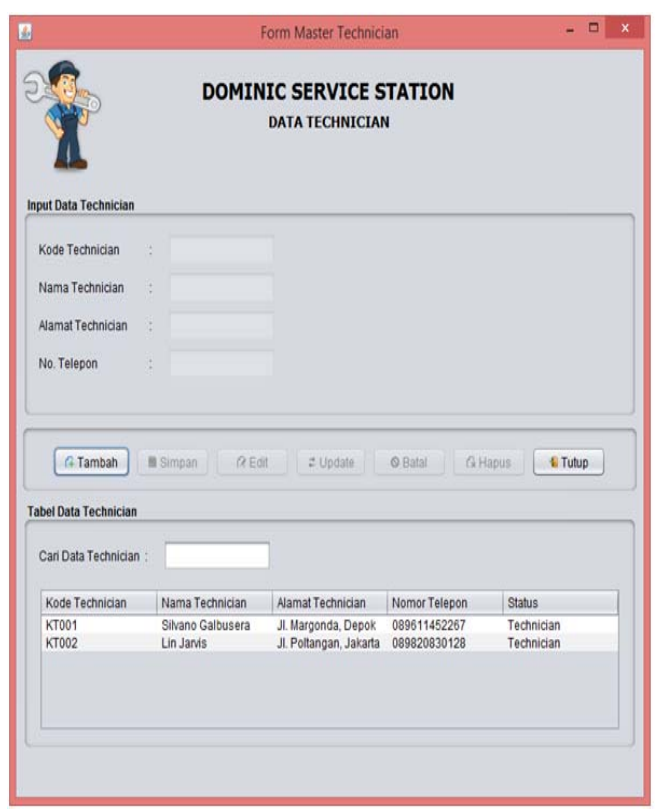

Gambar 12. User Interface Master Technician Aplikasi Penerimaan Jasa Service

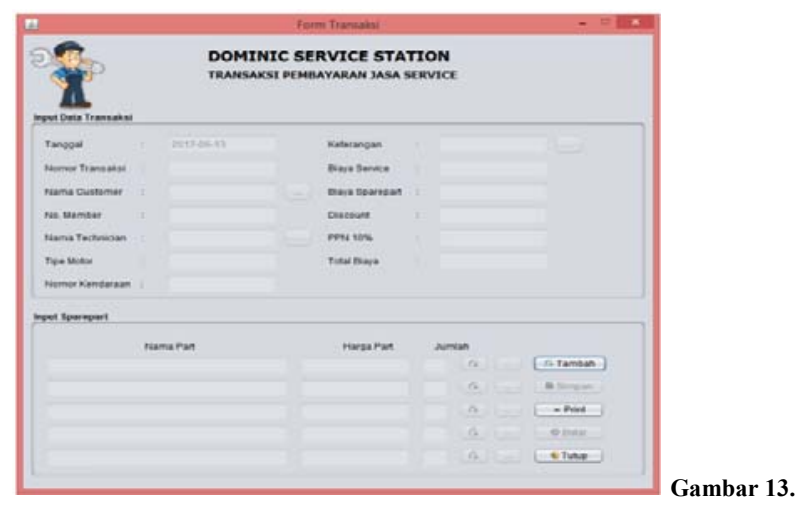

User Interface Transaksi Aplikasi Penerimaan Jasa Service
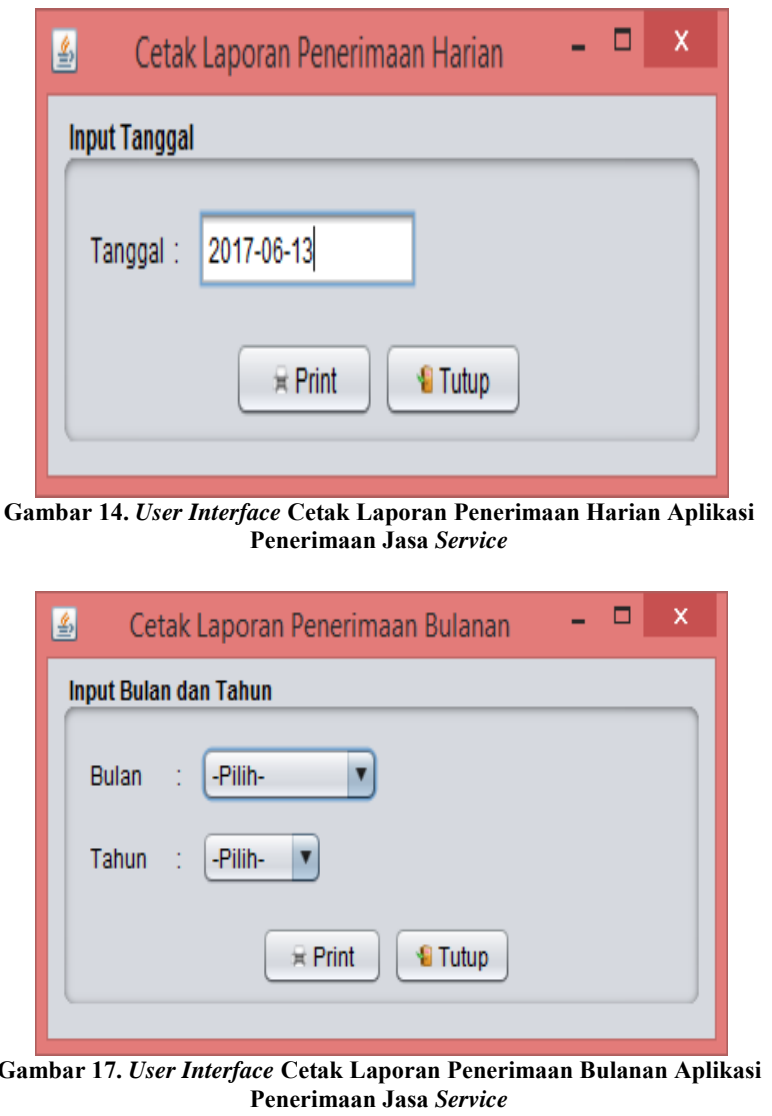

\subsection{Pengujian Black Box Testing}

Black box testing atau pengujian kotak hitam yaitu Menguji perangkat lunak dari segi spesifikasi fungsional tanpa menguji desain dan kode program. Pengujian dimaksudkan untuk mengetahui apakah fungsi-fungsi, masukan dan keluaran dari perangkat lunak sesuai dengan spesifikasi yang dibutuhkan [4].

Tabel 1. Hasil Black Box Testing Form Menu Master Jenis Service

\begin{tabular}{|c|l|l|l|l|l|}
\hline No & Skenario Pengujian & Test Case & Hasil Yang Diharapkan & $\begin{array}{c}\text { Hasil } \\
\text { Pengujian }\end{array}$ & Keterangan \\
\hline 1 & $\begin{array}{l}\text { Mengklik tombol } \\
\text { Tambah saat Form } \\
\text { Master Jenis Service } \\
\text { sudah muncul dan } \\
\text { kondisi awal tombol } \\
\text { Simpan, Edit, Update, } \\
\text { Batal dan Hapus dalam } \\
\text { kondisi nonaktif }\end{array}$ & & $\begin{array}{l}\text { Tombol Tambah berubah } \\
\text { menjadi nonaktif dan text } \\
\text { field untuk mengisi data } \\
\text { aktif atau bisa diinputkan } \\
\text { dan tombol Simpan, Batal } \\
\text { dan Tutup berubah mejadi } \\
\text { aktif }\end{array}$ & $\begin{array}{l}\text { Sesuai } \\
\text { harapan }\end{array}$ & Valid \\
\hline 2 & $\begin{array}{l}\text { Mengklik tombol } \\
\text { Tambah kemudian } \\
\text { mengosongkan semua } \\
\text { atau beberapa text field } \\
\text { penginputan data jenis } \\
\text { service dan selanjutnya } \\
\text { langsung mengklik }\end{array}$ & $\begin{array}{l}\text { Kode Service: } \\
\text { (kosong) } \\
\text { Keterangan: } \\
\text { (kosong) } \\
\text { Biaya Service: } \\
\text { (kosong) }\end{array}$ & $\begin{array}{l}\text { Sistem akan menolak atau } \\
\text { menunda proses } \\
\text { penyimpanan data } \\
\text { kedalam database dan } \\
\text { menampilkan notifikasi } \\
\text { "Lengkapi Data Terlebih } \\
\text { Dahulu" }\end{array}$ & $\begin{array}{l}\text { Sesuai } \\
\text { harapan }\end{array}$ & Valid \\
\\
\hline
\end{tabular}




\begin{tabular}{|c|c|c|c|c|c|}
\hline No & Skenario Pengujian & Test Case & Hasil Yang Diharapkan & $\begin{array}{c}\text { Hasil } \\
\text { Pengujian }\end{array}$ & Keterangan \\
\hline & tombol Simpan & & & & \\
\hline \multirow[t]{2}{*}{3} & $\begin{array}{l}\text { Mengklik salah satu } \\
\text { data didalam Tabel } \\
\text { Data Jenis Service }\end{array}$ & & $\begin{array}{l}\text { Sistem akan menampilkan } \\
\text { data yang dipilih } \\
\text { kemudian text field akan } \\
\text { terisi data }\end{array}$ & $\begin{array}{l}\text { Sesuai } \\
\text { harapan }\end{array}$ & Valid \\
\hline & & & $\begin{array}{l}\text { yang dipilih tersebut dan } \\
\text { tombol Edit, Batal, Hapus } \\
\text { dan Tutup dalam keadaan } \\
\text { aktif }\end{array}$ & & \\
\hline 4 & $\begin{array}{l}\text { Memilih data di dalam } \\
\text { Tabel Data Jenis } \\
\text { Service kemudian } \\
\text { mengklik tombol Edit, } \\
\text { setelah itu mengklik } \\
\text { tombol Update disaat } \\
\text { ada salah satu atau } \\
\text { lebih data belum terisi }\end{array}$ & $\begin{array}{l}\text { Kode Service: } \\
\text { SRG01 } \\
\text { Keterangan : } \\
\text { (kosong) } \\
\text { Biaya Service: } \\
30000\end{array}$ & $\begin{array}{l}\text { Sistem akan menolak atau } \\
\text { menunda proses } \\
\text { penyimpanan data } \\
\text { kedalam database dan } \\
\text { menampilkan notifikasi } \\
\text { "Lengkapi Data Terlebih } \\
\text { Dahulu" }\end{array}$ & $\begin{array}{l}\text { Sesuai } \\
\text { harapan }\end{array}$ & Valid \\
\hline 5 & Mengklik tombol Batal & & $\begin{array}{l}\text { Sistem akan } \\
\text { mengosongkan semua text } \\
\text { field pengisian data jenis } \\
\text { service }\end{array}$ & $\begin{array}{l}\text { Sesuai } \\
\text { harapan }\end{array}$ & Valid \\
\hline 6 & $\begin{array}{l}\text { Memilih data di dalam } \\
\text { tabel jenis service } \\
\text { kemudian mengklik } \\
\text { tombol Hapus } \\
\text { kemudian memilih } \\
\text { pilihan saat notifikasi } \\
\text { konfisrmasi muncul }\end{array}$ & & $\begin{array}{l}\text { Sistem akan menghapus } \\
\text { data yang dipilih dari } \\
\text { database, sebelumnya } \\
\text { akan menampilkan } \\
\text { notifikasi konfirmasi } \\
\text { "Yakin Data Jenis Service } \\
\text { (keterangan) Ingin } \\
\text { Dihapus?". Jika memilih } \\
\text { No akan muncul notifikasi } \\
\text { "Data Jenis Service } \\
\text { (keterangan) Batal } \\
\text { Dihapus" namun jika } \\
\text { memilih Yes akan muncul } \\
\text { notifikasi "Data Jenis } \\
\text { Service (keterangan) } \\
\text { Berhasil Dihapus" }\end{array}$ & $\begin{array}{l}\text { Sesuai } \\
\text { harapan }\end{array}$ & Valid \\
\hline 7 & $\begin{array}{l}\text { Mengklik tombol } \\
\text { Tutup }\end{array}$ & & $\begin{array}{l}\text { Sistem akan mengeluarkan } \\
\text { atau menutup Form Master } \\
\text { Jenis Service }\end{array}$ & $\begin{array}{l}\text { Sesuai } \\
\text { harapan }\end{array}$ & Valid \\
\hline 8 & $\begin{array}{l}\text { Menginputkan data } \\
\text { pada text field melebihi } \\
\text { jumlah batasan karakter } \\
\text { di dalam database yang } \\
\text { sudah ditentukan }\end{array}$ & $\begin{array}{l}\text { Kode Service: } \\
\text { SRG019090 } \\
\text { (melebihi } \\
\text { batas) } \\
\text { Keterangan : } \\
\text { Service \& ganti } \\
\text { oli } \\
\text { Biaya Service: } \\
30000\end{array}$ & $\begin{array}{l}\text { Sistem akan menghentikan } \\
\text { penginputan karakter } \\
\text { melalui keyboard jika } \\
\text { sudah mencapai batasan } \\
\text { karakter yang sudah } \\
\text { ditentukan di dalam } \\
\text { database }\end{array}$ & $\begin{array}{l}\text { Sesuai } \\
\text { harapan }\end{array}$ & Valid \\
\hline 9 & $\begin{array}{l}\text { Menklik tombol } \\
\text { Tambah kemudian } \\
\text { dilanjutkan dengan } \\
\text { mengisi text field } \\
\text { sesuai dengan } \\
\text { ketentuan dan langsung } \\
\text { mengklik tombol } \\
\text { Simpan } \\
\end{array}$ & $\begin{array}{l}\text { Kode Service: } \\
\text { SRG01 } \\
\text { Keterangan : } \\
\text { Service \& ganti } \\
\text { oli } \\
\text { Biaya Service : } \\
30000\end{array}$ & $\begin{array}{l}\text { Sistem akan menyimpan } \\
\text { data yang telah diinputkan } \\
\text { ke dalam database } \\
\text { kemudian memunculkan } \\
\text { notifikasi "Data Jenis } \\
\text { Service (keterangan) } \\
\text { Berhasil Disimpan" }\end{array}$ & $\begin{array}{l}\text { Sesuai } \\
\text { harapan }\end{array}$ & Valid \\
\hline
\end{tabular}




\begin{tabular}{|c|l|l|l|l|l|}
\hline No & Skenario Pengujian & \multicolumn{1}{|c|}{ Test Case } & Hasil Yang Diharapkan & $\begin{array}{c}\text { Hasil } \\
\text { Pengujian }\end{array}$ & Keterangan \\
\hline 10 & $\begin{array}{l}\text { Melakukan proses } \\
\text { pencarian data jenis } \\
\text { service berdasarkan } \\
\text { kode service atau } \\
\text { keterangan baik dengan } \\
\text { menginputkan secara } \\
\text { lengkap atau tidak }\end{array}$ & $\begin{array}{l}\text { Cari Data Jenis } \\
\text { Service }: \text { SRG }\end{array}$ & $\begin{array}{l}\text { Sistem akan menampilkan } \\
\text { hasil pencarian pada tabel } \\
\text { data jenis service. }\end{array}$ & $\begin{array}{l}\text { Sesuai } \\
\text { harapan }\end{array}$ & Valid \\
\hline
\end{tabular}

\section{A. Kesimpulan}

\section{KESIMPULAN dan SARAN}

Dari analisis sampai implementasi sistem maka dapat diambil kesimpulan bahwa pengembangan sistem informasi penerimaan jasa dapat membantu organisasi dan perusahan kecil bengkel secara cepat dalam proses transaksi. Serta pengguna dapat mudah memahami cara penggunaan sistem terkomputerisasi untuk mendukung proses penerimaan jasa service dikarenakan tampilan yang digunakan bersifat user friendly. Sistem ini juga mendukung pengolahan data master, transaksi hingga menampilkan laporan yang dibutuhkan, serta sistem ini mendukung adanya hak akses dan perekaman siapa saja yang menggunakan sistem. Dengan menggunakan program aplikasi penerimaan jasa service pada bengkel sepeda motor diharapkan dapat mempercepat proses pengolahan data transaksi penerimaan jasa service sampai dengan proses pembuatan laporan sehingga waktu yang dibutuhkan untuk mengolah data tersebut relatif lebih singkat. Untuk kedepannya akan dikembangkan fitur-fitur baru yang dapat digunakan oleh pengguna di dalam sistem.

\section{B. Saran}

Penulis menyadari bahwa pada Sistem informasi penerimaan Jasa di Bengkel dan tata letak yang diusulkan ini masih memiliki beberapa kekurangan, untuk itu apabila penelitian ini ingin dilanjutkan, penulis ingin memberi beberapa saran yaitu dikembangkan lagi menyesuaikan dengan Teknologi yang lebih Up To Date.

\section{Referensi}

[1] M. R. Arief, Pemrograman Web Dinamis menggunakan PHP dan MYSQL, Yogyakarta: Andi Offset, 2011.

[2] V. D. Mariani, “Analisis Dan Perancangan Sistem Informasi Akuntansi Penjualan, Piutang Dan Penerimaan Kas Pada CV. Dekatama. Seminar Nasional Aplikasi Teknologi Informasi (pp. B-23)," Yogyakarta.Hasugian,
2010.

[3] A. I. J. Putra, "Perancangan Sistem Informasi Berbasis Teknologi Dengan Menggunakan Metode Rapid
Application Development (RAD) Pada Bengkel Wijaya Motor," 26 Oktober 2017. [Online]. Available: http://repository.unika.ac.id/id/eprint/14932.

[4] Rosa dan M. Shalahuddin, Rekayasa Perangkat Lunak Terstruktur dan Berorientasi Objek, Bandung: Informatika Bandung, 2013.

[5] H. \&. S. A. N. Hasugian, "Rancang Bangun Sistem Informasi Industri Kreatif Bidang Penyewaan Sarana Olahraga," dalam Seminar Nasional Teknologi Informasi \& Komunikasi Terapan, Semarang, 2012.

[6] I. G. H. B. Noerlina, Perancangan Sistem Informasi Berbasis Object Oriented Studi Kasus, Jakarta: Mitra Wacana, 2007.

[7] Munir, R. (2011). Algoritma dan Pemrograman. Jakarta: Informatika.

[8] Yulikuspartono. (2009). Pengantar Logika dan Algoritma. Yogyakarta: Andi Offset.

[9] Yuhefijar. (2008). Konsep Dasar Sistem Informasi Akuntansi. Jakarta: Salemba Empat.

[10] Nugroho, A. (2010). Rekayasa Perangakt Lunak Berorientasi Objek dengan Metode USDP. Yogyakarta: Andi.

[11] Hadi, H., \& Hastuti, D. (2011). Kamus Terbaru Ekonomi dan Bisnis. Surabaya: Reality Publisher.

[12] Jusup, A. H. (2011). Dasar-Dasar Akuntansi Jilid 1. Yogyakarta: Sekolah Tinggi Ilmu Ekonomi YKPN.

[13] Rosa dan Shalahuddin. (2013). Rekayasa Perangkat Lunak Terstruktur dan Berorientasi Objek. Bandung: Informatika.

, H., \& Shiddiq, A. N. (2012). Rancangan Bangun Sistem Informasi Industri Kreatif Bidang Penyewaan Sarana Olahraga. Semarang: Semantik. 